Brit. Heart f., 1969, 31, 693.

\title{
The Apex Cardiogram in Left Bundle-branch Block
}

\author{
DANIEL E. SANTOS, ADRIANO DE LA PAZ, RAYMOND J. PIETRAS, \\ JOHN R. TOBIN, JR., AND ROLF M. GUNNAR

\begin{abstract}
From the Department of Adult Cardiology and the Hektoen Institute for Medical Research of Cook County Hospital, Chicago, Illinois; and from the Departments of Medicine of the University of Illinois College of Medicine and the Loyola University Stritch School of Medicine, Hines, Illinois, U.S.A.
\end{abstract}

The apex cardiogram and its relation to intracardiac events has been well studied (Benchimol and Dimond, 1963; Tafur, Cohen, and Levine, 1964; Tavel et al., 1965; Coulshed and Epstein, 1963). This simple clinical procedure can be used to determine the length of isovolumic contraction, and this may relate to the state of myocardial contractility (Sambhi, 1960; Reeves et al., 1960; Siegel and Sonnenblick, 1963; Wallace et al., 1963), or to changes in conduction within the ventricle.

This study was undertaken to determine if the apex cardiogram in the presence of left bundlebranch block would serve to differentiate patients with myocardial infarction from patients without myocardial infarction. The presence or absence of myocardial infarction was determined by vectorcardiogram, using previously described criteria (Neuman et al., 1965; Doucet, Walsh, and Massie, 1966).

\section{SuBJECTS AND METHODS}

Studies were made of $\mathbf{4 0}$ patients. History, physical examination, and a standard 12-lead electrocardiogram were obtained. A vectorcardiogram was recorded on all patients, using the Frank corrected lead system. Heart sounds were recorded from the second and third left intercostal spaces along the left sternal border with two crystal microphones. The carotid arterial pulse was simultaneously recorded with an AC excited differential transformer transducer. The apex cardiogram was recorded according to the method of Benchimol and Dimond (1963). Heart sounds were recorded simultaneously from the fourth left intercostal space and apex. The apex cardiogram was obtained in the supine position if a good apical impulse was felt, or in the lateral decubitus if this position improved the quality of the tracings. All tracings were recorded on photographic paper at a speed of $75 \mathrm{~mm}$. per second, using a HewlettPackard model No. 564 four-channel recorder. Nine patients had cardiac catheterization, and aortic and left

Received February 10, 1969. ventricular pulse, electrocardiogram, phonocardiogram, and apex cardiogram were recorded simultaneously. Coronary cine-angiograms were also carried out on these 9 patients.

The following measurements were made on the apex cardiogram and left ventricular pulse, as illustrated in Fig. 1 and 2, respectively.

(A) Apex cardiogram: (1) Isovolumic contraction period (IC) $=N_{1}$ or $S_{1}$ to $E$ point; (2) ventricular systole (VS) $=N_{1}$ or $S_{1}$ to $N_{2}$ or $S_{2} A$ (thus including protodiastole); (3) ventricular ejection $(V E)=E$ point to $N_{2}$ or $S_{2} A=V S-I C ;(4)$ isovolumic relaxation (IR) $=S_{2} A$ or $\mathrm{N}_{2}$ to $\mathrm{O}$ point.

(B) Left ventricular pressure pulse: (1) Isovolumic contraction period-beginning of the ventricular pulse to the aortic opening or $S_{1}$ or $N_{1}$ to $E$ point; (2) ventricular systole-beginning of the ascending limb of the ventricular pulse to the aortic closure or $S_{1}$ or $N_{1}$ to $S_{2} A$ or $N_{2}$ (thus including protodiastole); (3) ventricular ejection-from the aortic opening to aortic closure or $\mathrm{VE}=\mathrm{VS}-\mathrm{IC}$; (4) Isovolumic relaxation-aortic closure to the end of the descending limb of the ventricular pulse or $O$ point.

When the first notch was not seen on the apex cardiogram, the component of the first sound $\left(S_{1}\right)$ with the greatest amplitude was used for reference. In this study this component was found to be at or close to $\mathrm{N}_{1}$ without any significant delay. This was also true for the aortic component of the second sound $\left(S_{2} A\right)$ in reference for the second notch $\left(\mathrm{N}_{2}\right)$. The ejection point $(\mathrm{E})$ and the end of isovolumic relaxation ( $O$ point) were consistently distinct.

The patients were divided into two groups: Group I, patients with left bundle-branch block and no historical or vectorcardiographic evidence of myocardial infarction, and Group II, patients with left bundle-branch block complicated by vectorcardiographic evidence of myocardial infarction.

There were 15 patients in Group $I$ and 25 patients in Group II. The total group included 14 women and 26 men ranging in age from 33 to 88 , with an average of 57.8 years. The significant clinical data are shown in Table I. Arteriosclerotic or hypertensive heart disease was diagnosed in 31 patients and primary myocardial disease in 9. 


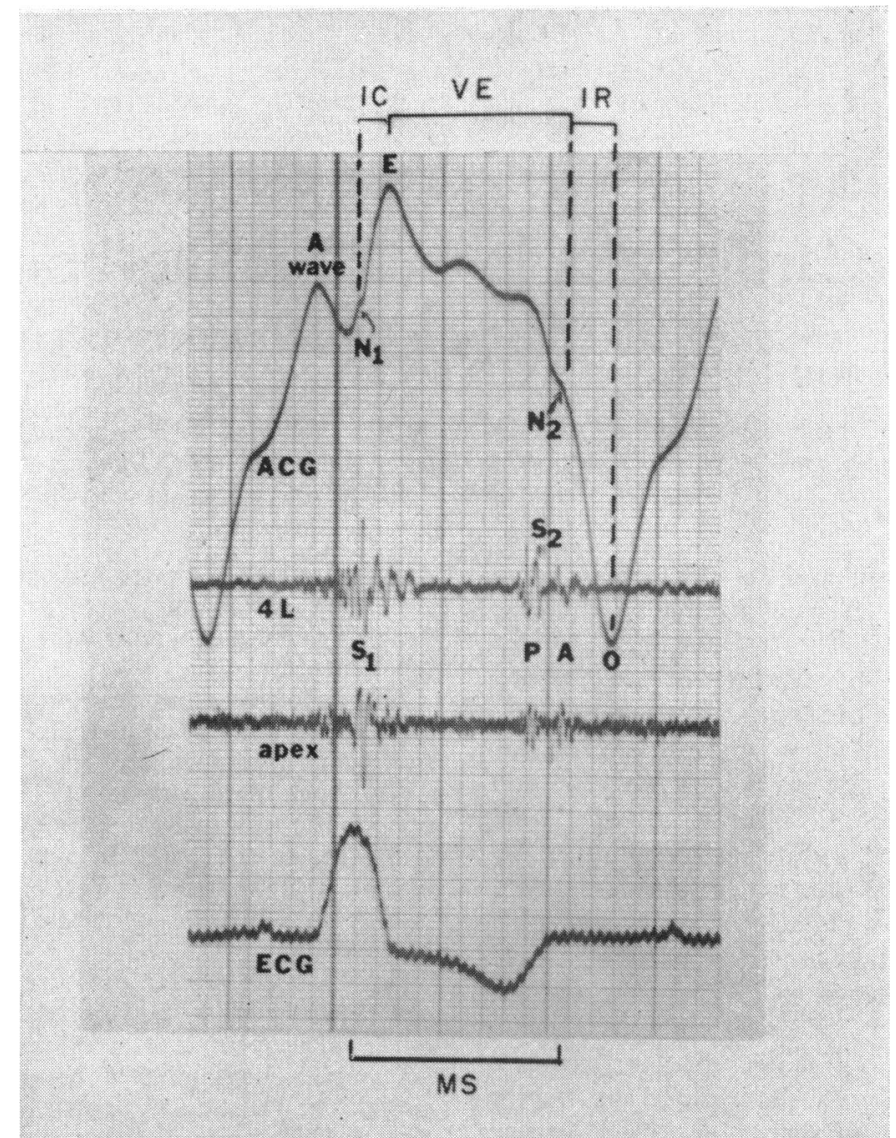

FIG. 1.-Apex cardiogram (ACG), phonocardiogram at fourth left interspace (4L), and apex and electrocardiogram (ECG) showing the time intervals: isovolumic contraction (IC), ventricular ejection (VE), isovolumic relaxation (IR), and mechanical systole (MS).

Hypertension (systolic greater than $150 \mathrm{~mm} . \mathrm{Hg}$ and/ or diastolic greater than $90 \mathrm{~mm}$. $\mathrm{Hg}$ ) was present in 18 patients for a period of from 4 days to 20 years, with an average of 7.8 years (Tables I and II). The means of the blood pressures were not significantly different between the two groups (Table II). The mean of the blood pressures for the whole group was $137 / 85 \mathrm{~mm} . \mathrm{Hg}$. Angina was experienced by 22 patients, $19(68.5 \%)$ of whom were in Group II. The average duration of anginal symptoms was 2.9 years (range-4 hours to 10 years). Congestive heart failure was present in 31 patients for a period of from 2 weeks to 10 years, with an average of 2.6 years. Eighteen patients with cardiac failure were in Group II and 13 patients in Group I. However, all patients were considered by clinical criteria to be compensated at the time of the study.

All but 12 patients had retinal arteriolar changes ranging from grade I to III (Keith, Wagener, and Barker, 1939). Thirty-seven patients had various degrees of left ventricular hypertrophy, and only 3 patients had normal-sized hearts on physical examination (Santos et al., 1966) (Table I).
Seven patients in Group II had had severe chest pain, but all had been convalescing for several weeks. Two of these patients had experienced syncope. All $7 \mathrm{had}$ had raised enzyme levels suggestive of myocardial infarction (LaDue, Wróblewski, and Karmen, 1954; Stewart and Warburton, 1961). The serum aspartate aminotransferase in these patients had ranged from 55 to 145 units, with an average of 89 units, and serum lactic dehydrogenase had ranged from 810 to 1575 units, with an average of 1258 units.

All 40 patients had paradoxical splitting of the second heart sound and diminished first heart sounds.

\section{Results}

The most consistent differences in the apex cardiogram between the two groups were the durations of the isovolumic contraction period and the ventricular ejection period. The averages for the isovolumic contraction and ventricular ejection were 0.12 sec. and 0.205 sec., respectively, in Group I, 


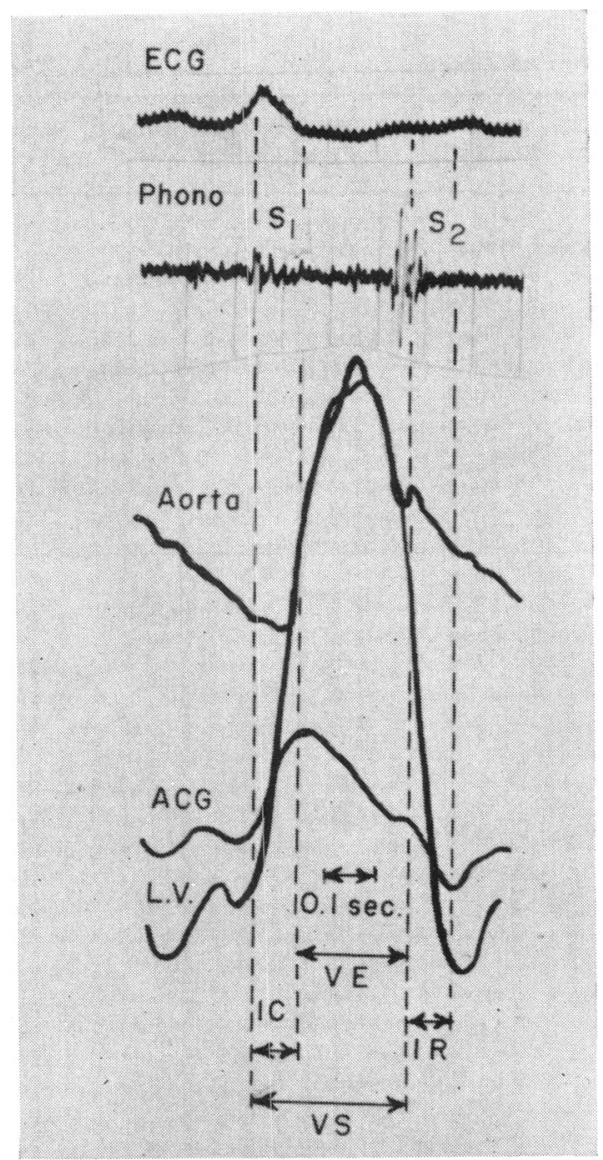

FIG. 2.-Left ventricular pressure (LV), aortic pressure, apex cardiogram (ACG) showing the time intervals: ventricular systole (VS), ventricular ejection (VE), isovolumic contraction (IC), and isovolumic relaxation (IR).

and 0.076 sec. and 0.240 sec. in Group II. Of the 15 patients in Group I, 11 had an isovolumic contraction period of $0.12 \mathrm{sec}$. or greater, whereas of the 25 patients in Group II, 23 had contraction times of less than $0 \cdot 12 \mathrm{sec}$. Left ventricular systole and isovolumic relaxation were not significantly different in the two groups (Table III).

Heart rate was not significantly different between the two groups. When isovolumic contraction and ventricular ejections were corrected for the heart rate (IC or VE $/ \sqrt{\mathbf{R}-\mathrm{R}}$ ), the mean isovolumic contraction was $0.14 \mathrm{sec}$. in Group I and $0.09 \mathrm{sec}$. in Group II. The ventricular ejection was found to

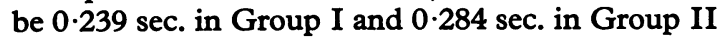
(Table IV).

Of the 9 patients who were catheterized, 3 belonged to Group I and 6 to Group II. In these patients the corrected isovolumic contraction was found to be $0.139 \mathrm{sec}$. in Group I and $0.09 \mathrm{sec}$. in Group II, while the ventricular ejection was 0.236 sec. in Group I and $0.31 \mathrm{sec}$. in Group II, as measured from the ventricular pulse. As with the apex cardiogram, no significant differences were noted in ventricular systole and ventricular ejection between the two groups. Coronary cine-angiograms confirmed the presence of coronary artery disease in the 6 patients in Group II, and no evidence of coronary artery disease was found in the 3 patients in Group I (Table V).

All patients in Group I and 18 patients in Group II had sinus rhythm. Seven patients in Group II had atrial fibrillation. No other arrhythmias were found except for occasional premature atrial and ventricular contractions.

In Group II left ventricular free wall infarction was diagnosed by the vectorcardiograms in 9 patients, septal infarction in 6, apical infarction in 4, combined apical and free wall infarction in 4, and posterior infarction in 2 (Table III).

\section{Discussion}

Lewis in 1934 reported 14 patients with bundlebranch block and noted that the apex impulse was normal in 8 patients. The following year, Wolferth and Margolies (1935) reported 5 patients with left bundle-branch block and described a delay in left ventricular ejection and aortic closure. Coblentz et al. (1949) noted that the onset of the left ventricular pressure pulse was not delayed in left bundlebranch block and that the first heart sound was not split. Leatham (1954) observed, in addition, that the rise in pressure during the isovolumic contraction period was prolonged. Gray (1956) reported 18 patients with left bundle-branch block, and described paradoxical splitting of the second heart sound ranging between 0.02 to 0.06 sec. Braunwald and Morrow (1957), in haemodynamic studies, confirmed the previous reports (Lewis, 1934; Coblentz et al., 1949) that the onset of ventricular ejection was delayed due to a conduction block in some of the branches of the left main bundle or within the ventricular myocardium. The anatomy of the main bundle (Kistin, 1949) is such that many instances of left bundle-branch block as identified by electrocardiographic criteria are due to arborization block (Haber and Leatham, 1965).

Though necropsy studies are lacking in our series, the majority of our patients in Group II have had typical angina for varying lengths of time. Seven of these patients had severe angina before admission, and the enzyme levels were raised, suggesting recent myocardial infarction. Furthermore, the vectorcardiographic criteria for myocardial infarction were 
TABLE I

CLINICAL FINDINGS IN 40 PATIENTS

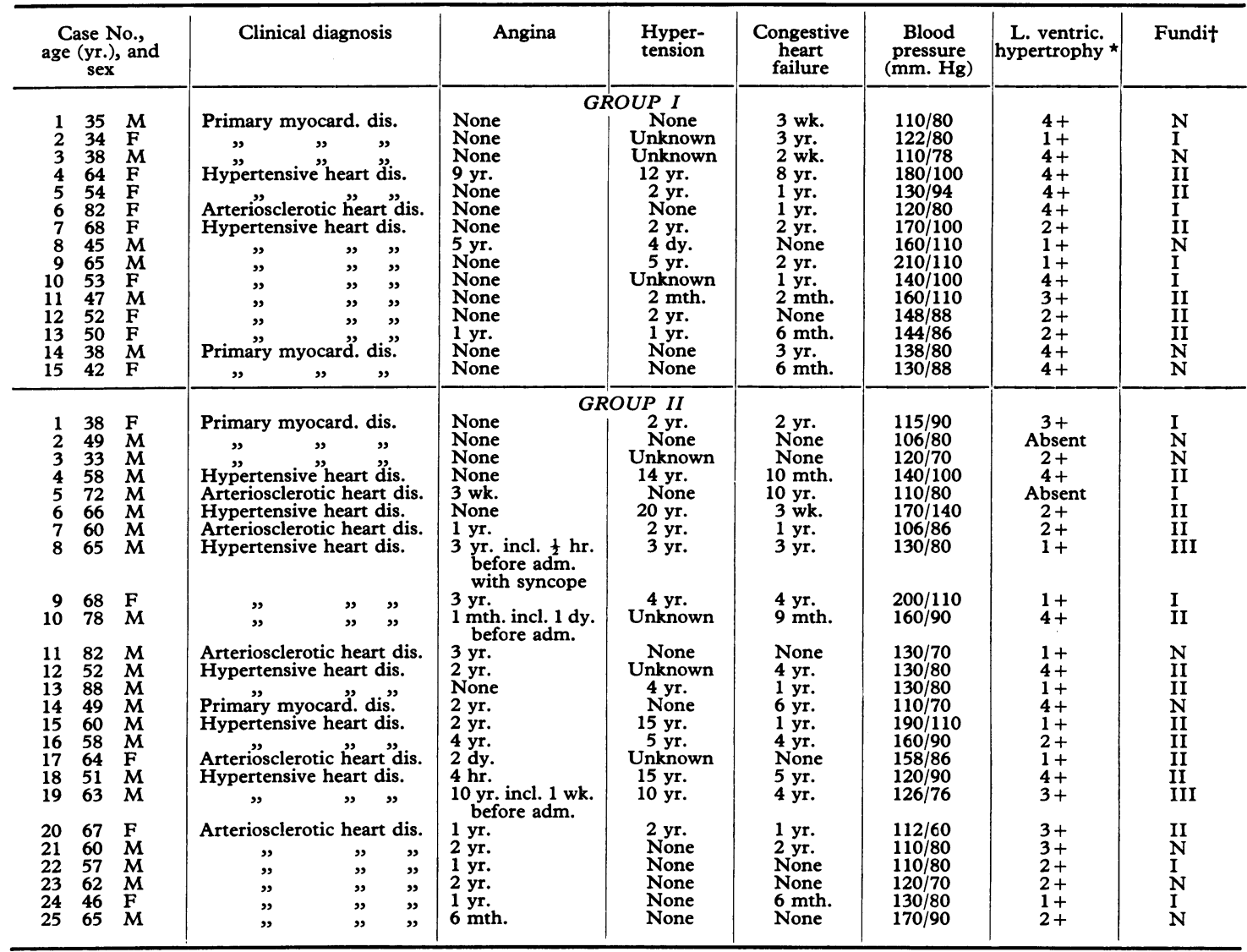

* Left ventricular hypertrophy was graded from mild (1) to severe (4).

† Keith-Wagener-Barker classification.

TABLE II

SUMMARY OF CLINICAL DATA GIVING NUMBER OF PATIENTS IN EACH GROUP

\begin{tabular}{c|c|c|c|c|c|c|c}
\hline Group & Total & Angina & $\begin{array}{c}\text { Hyper- } \\
\text { tension }\end{array}$ & $\begin{array}{c}\text { Congestive } \\
\text { heart } \\
\text { failure }\end{array}$ & $\begin{array}{c}\text { Primary } \\
\text { myocardial } \\
\text { disease }\end{array}$ & $\begin{array}{c}\text { Arteriosclerotic } \\
\text { and hypertensive } \\
\text { heart disease }\end{array}$ \\
\hline I & 15 & 3 & 6 & $\begin{array}{c}\text { Average blcod } \\
\text { pressure } \\
\text { (mm. Hg) }\end{array}$ \\
\hline II & 25 & 19 & 12 & 13 & 5 & 10 \\
\hline Total & 40 & 22 & 18 & 31 & 9 & $143 \cdot 3 / 87.1$ \\
\hline
\end{tabular}

satisfied. The vectorcardiographic diagnosis of infarction in the presence of left bundle-branch block has been correlated with necropsy and clinical data (Neuman et al., 1965; Doucet et al., 1966). In addition, the presence of coronary artery disease was confirmed by coronary cine-angiography in all six patients belonging to Group II who had cardiac catheterization.
Our findings in Group I (patients without infarction) are in accord with observations made by others (Wolferth and Margolies, 1935; Leatham, 1954; Haber and Leatham, 1965; Bourassa, Boiteau, and Allenstein, 1962). The prolonged isovolumic contraction in left bundle-branch block has been thought to be due to the abnormal spread of the activation wave through the left ventricle (Braun- 
TABLE III

APEX CARDIOGRAM MEASUREMENTS AND VECTORCARDIOGRAPHIC DIAGNOSIS IN 40 PATIENTS

\begin{tabular}{|c|c|c|c|c|c|c|c|c|c|c|c|c|}
\hline $\begin{array}{l}\text { Case } \\
\text { No. }\end{array}$ & $\begin{array}{c}\text { Heart } \\
\text { rate }\end{array}$ & $\begin{array}{l}\text { Mechani- } \\
\text { cal } \\
\text { systole } \\
\text { (sec.) }\end{array}$ & $\begin{array}{c}\text { Iso- } \\
\text { volumic } \\
\text { contrac- } \\
\text { tion (sec.) }\end{array}$ & $\frac{I C}{\sqrt{\mathrm{R}-\mathrm{R}}}$ & $\begin{array}{l}\text { Ventricu- } \\
\text { lar } \\
\text { ejection } \\
\text { (sec.) }\end{array}$ & $\frac{V E}{\sqrt{\mathrm{R}-\mathrm{R}}}$ & $\begin{array}{c}\text { Iso- } \\
\text { volumic } \\
\text { relaxation } \\
(\text { sec. })\end{array}$ & \multicolumn{5}{|c|}{ Vectorcardiographic diagnosis } \\
\hline $\begin{array}{r}1 \\
2 \\
3 \\
4 \\
5 \\
6 \\
7 \\
8 \\
9 \\
10 \\
11 \\
12 \\
13 \\
14 \\
15\end{array}$ & $\begin{array}{r}86 \\
82 \\
104 \\
90 \\
91 \\
77 \\
60 \\
75 \\
84 \\
84 \\
85 \\
100 \\
75 \\
85 \\
120\end{array}$ & $\begin{array}{l}0.360 \\
0.298 \\
0.280 \\
0.265 \\
0.320 \\
0.360 \\
0.325 \\
0.400 \\
0.280 \\
0.340 \\
0.290 \\
0.338 \\
0.339 \\
0.440 \\
0.282\end{array}$ & $\begin{array}{l}0.160 \\
0.100 \\
0.158 \\
0.120 \\
0.120 \\
0.085 \\
0.125 \\
0.150 \\
0.060 \\
0.120 \\
0.090 \\
0.133 \\
0.132 \\
0.125 \\
0.139 \\
\end{array}$ & $\begin{array}{l}0.192 \\
0.117 \\
0.208 \\
0 \cdot 147 \\
0.148 \\
0.096 \\
0 \cdot 125 \\
0 \cdot 168 \\
0.071 \\
0 \cdot 142 \\
0 \cdot 107 \\
0 \cdot 157 \\
0 \cdot 144 \\
0 \cdot 125 \\
0 \cdot 172 \\
\end{array}$ & $\begin{array}{l}0.200 \\
0.198 \\
0.122 \\
0.145 \\
0.200 \\
0.275 \\
0.200 \\
0.250 \\
0.240 \\
0.220 \\
0.200 \\
0.205 \\
0.207 \\
0.317 \\
0.142 \\
\end{array}$ & $\begin{array}{c}\text { GROUP } \\
0.239 \\
0.231 \\
0.161 \\
0.177 \\
0.246 \\
0.311 \\
0.200 \\
0.279 \\
0.284 \\
0.260 \\
0.238 \\
0.240 \\
0.220 \\
0.317 \\
0.178\end{array}$ & $\begin{array}{l}0.110 \\
0.080 \\
0.100 \\
0.120 \\
0.115 \\
0.085 \\
0.100 \\
0.120 \\
0.060 \\
0.120 \\
0.110 \\
0.114 \\
0.120 \\
0.117 \\
0.119 \\
\end{array}$ & $\begin{array}{r}\text { Left } \\
\text { " } \\
\text { " } \\
\text { " } \\
\text { " } \\
" \\
\text { " } \\
\text { " } \\
\text { " }\end{array}$ & $\begin{array}{l}\text { Ind } \\
\text { " } \\
\text { ", } \\
\text { " } \\
\text { " } \\
\text { " } \\
\text { " } \\
\text { " } \\
\text { " }\end{array}$ & $\begin{array}{l}\text { ran } \\
\text { " } \\
\text { ", } \\
\text { "' } \\
\text { " } \\
\text { " } \\
\text { ", } \\
\text { " } \\
\text { " }\end{array}$ & $\begin{array}{l}\text { lock } \\
" \\
\text { " } \\
\text { " } \\
\text { " } \\
\text { " } \\
\text { " } \\
\text { " } \\
\text { " }\end{array}$ & \\
\hline $\begin{array}{r}1 \\
2 \\
3 \\
4 \\
5 \\
6 \\
7 \\
8 \\
9 \\
10 \\
11 \\
12 \\
13 \\
14 \\
15 \\
16 \\
17 \\
18 \\
19 \\
20 \\
21 \\
22 \\
23 \\
24 \\
25\end{array}$ & $\begin{array}{r}100 \\
60 \\
100 \\
106 \\
107 \\
65 \\
110 \\
84 \\
84 \\
62 \\
71 \\
90 \\
79 \\
70 \\
81 \\
107 \\
81 \\
100 \\
88 \\
100 \\
86 \\
85 \\
60 \\
100 \\
109\end{array}$ & $\begin{array}{l}0.360 \\
0.440 \\
0.312 \\
0.300 \\
0.280 \\
0.290 \\
0.300 \\
0.310 \\
0.320 \\
0.360 \\
0.360 \\
0.280 \\
0.370 \\
0.340 \\
0.290 \\
0.280 \\
0.340 \\
0.280 \\
0.290 \\
0.332 \\
0.298 \\
0.318 \\
0.307 \\
0.260 \\
0.294\end{array}$ & $\begin{array}{l}0.135 \\
0.100 \\
0.060 \\
0.085 \\
0.060 \\
0.070 \\
0.050 \\
0.065 \\
0.075 \\
0.060 \\
0.140 \\
0.070 \\
0.060 \\
0.090 \\
0.040 \\
0.070 \\
0.060 \\
0.070 \\
0.095 \\
0.080 \\
0.080 \\
0.080 \\
0.080 \\
0.050 \\
0.064\end{array}$ & $\begin{array}{l}0.174 \\
0.100 \\
0.077 \\
0.113 \\
0.080 \\
0.073 \\
0.068 \\
0.077 \\
0.089 \\
0.061 \\
0.152 \\
0.086 \\
0.069 \\
0.097 \\
0.046 \\
0.093 \\
0.070 \\
0.090 \\
0.115 \\
0.100 \\
0.100 \\
0.100 \\
0.100 \\
0.060 \\
0.073\end{array}$ & 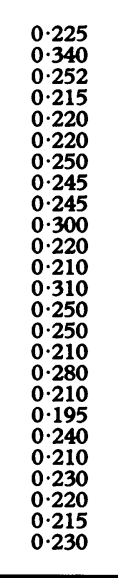 & $\begin{array}{c}\text { GROUP } \\
0.290 \\
0.340 \\
0.324 \\
0.286 \\
0.294 \\
0.229 \\
0.339 \\
0.290 \\
0.290 \\
0.305 \\
0.239 \\
0.257 \\
0.356 \\
0.270 \\
0.290 \\
0.280 \\
0.325 \\
0.271 \\
0.237 \\
0.270 \\
0.256 \\
0.266 \\
0.261 \\
0.281 \\
0.255\end{array}$ & $\begin{array}{l}0.100 \\
0.070 \\
0.075 \\
0.060 \\
0.060 \\
0.080 \\
0.090 \\
0.100 \\
0.080 \\
0.130 \\
0.110 \\
0.100 \\
0.090 \\
0.080 \\
0.150 \\
0.060 \\
0.100 \\
0.080 \\
0.100 \\
0.118 \\
0.139 \\
0.132 \\
0.102 \\
0.091 \\
0.125\end{array}$ & $\begin{array}{r}\text { Left } \\
\text { " } \\
\text { " } \\
\text { " } \\
\text { " } \\
\text { " } \\
\text { " } \\
\text { " } \\
\text { " } \\
\text { " } \\
\text { " } \\
\text { " } \\
\text { " } \\
\text { " } \\
\text { " }\end{array}$ & $\begin{array}{l}\text { Ind } \\
\text { ", } \\
\text { ", } \\
\text { ", } \\
\text { ", } \\
\text { " } \\
\text { " } \\
\text { ", } \\
\text { ", } \\
\text { ", } \\
\text { ", } \\
\text { "' } \\
\text { ", }\end{array}$ & $\begin{array}{l}\text { ran } \\
\text { ", } \\
\text { "' } \\
\text { " } \\
\text { "' } \\
\text { " } \\
\text { " } \\
\text { " } \\
\text { " } \\
\text { " } \\
\text { " } \\
\text { " } \\
\text { " } \\
\text { " }\end{array}$ & $\begin{array}{l}\text { "lock } \\
\text { "' } \\
\text { "' } \\
\text { "' } \\
\text { "' } \\
\text { " } \\
\text { "' } \\
\text { "' } \\
\text { " } \\
\text { "' } \\
\text { "' }\end{array}$ & $\begin{array}{l}\text { + septal infarct } \\
\text { + lateral wall infarct } \\
\text { + free wall infarct } \\
\text { + apical infarct } \\
\text { + septal infarct } \\
\text { + apico-lateral infarct } \\
\text { + lateral wall infarct } \\
\text { + posterior infarct } \\
\text { + apical infarct } \\
\text { + lateral wall infarct } \\
\text { + lateral wall infarct } \\
\text { + apical infarct } \\
\text { + apico-lateral infarct } \\
\text { + apico-lateral infarct } \\
\text { + lateral wall infarct } \\
\text { + septal infarct } \\
\text { + lateral wall infarct } \\
\text { + lateral wall infarct } \\
\text { + septal infarct } \\
\text { + posterior infarct } \\
\text { + lateral wall infarct } \\
\text { + septal infarct } \\
\text { + septal infarct } \\
\text { + apical infarct } \\
\text { + apical infarct }\end{array}$ \\
\hline
\end{tabular}

TABLE IV

AVERAGE APEX CARDIOGRAM MEASUREMENTS

\begin{tabular}{|c|c|c|c|c|c|c|c|}
\hline Group & $\begin{array}{c}\text { Heart } \\
\text { rate }\end{array}$ & $\begin{array}{c}\text { Isovolumic } \\
\text { contraction } \pm \mathrm{SD}\end{array}$ & $\sqrt{\sqrt{\mathrm{R}-\mathrm{R}}} \pm \mathrm{SD}$ & $\begin{array}{l}\text { Ventricular } \\
\text { systole }\end{array}$ & $\begin{array}{r}\text { Ventricular } \\
\text { ejection } \pm S D\end{array}$ & $\sqrt{\sqrt{R E}-R} \pm S D$ & $\begin{array}{l}\text { Isovolumic } \\
\text { relaxation }\end{array}$ \\
\hline II & $\begin{array}{l}83 \cdot 0 \\
77 \cdot 2\end{array}$ & $\begin{array}{l}0.12 \pm 0.03 \\
0.076 \pm 0.004\end{array}$ & $\begin{array}{l}0.14 \pm 0.03 \\
0.09 \pm 0.03\end{array}$ & $\begin{array}{l}0.32 \\
0.316\end{array}$ & $\begin{array}{l}0.205 \pm 0.04 \\
0.240 \pm 0.03\end{array}$ & $\begin{array}{l}0.239 \pm 0.04 \\
0.284 \pm 0.05\end{array}$ & $\begin{array}{l}0 \cdot 10 \\
0.096\end{array}$ \\
\hline \multicolumn{2}{|c|}{ Probability } & $>0.01<0.02$ & $<0.0005$ & $<0.45$ & $>0.01<0.02$ & $<0.001$ & $>0.45<0.475$ \\
\hline
\end{tabular}

All values are in seconds except the heart rate. Isovolumic contraction and ventricular ejection were corrected (IC/R-R and VE/R-R) for heart rate. Ventricular systole, isovolumic relaxation, and heart rate were not significantly different.

TABLE V

AVERAGE MEASUREMENTS FROM LEFT VENTRICULAR PRESSURE PULSE CORRECTED FOR HEART RATE SAVE FOR VENTRICULAR SYSTOLE AND ISOVOLUMIC EJECTION

\begin{tabular}{c|c|c|c|c|c|c}
\hline $\begin{array}{c}\text { No. of } \\
\text { cases }\end{array}$ & Group & $\begin{array}{c}\text { Isovolumic } \\
\text { contraction } \pm \text { SD }\end{array}$ & $\begin{array}{c}\text { Ventricular } \\
\text { systole }\end{array}$ & $\begin{array}{c}\text { Ventricular } \\
\text { ejection } \pm \text { SD }\end{array}$ & $\begin{array}{c}\text { Isovolumic } \\
\text { relaxation }\end{array}$ & Coronary cine-angiogram \\
\hline 3 & I & $\begin{array}{c}0.139 \pm 0.017 \\
0.09 \pm 0.004\end{array}$ & $\begin{array}{l}0.39 \\
0.40\end{array}$ & $\begin{array}{c}0.236 \pm 0.05 \\
0.310 \pm 0.05\end{array}$ & $\begin{array}{l}0.132 \\
0.138\end{array}$ & $\begin{array}{c}\text { No evidence of coronary artery disease in all 3 } \\
\text { 2 patients with attenuated anterior descending branch } \\
\text { of left coronary; } 4 \text { patients with stenosis of right } \\
\text { coronary and anterior descending branch of left } \\
\text { coronary }\end{array}$ \\
\hline Probability & $<0.0005$ & & $<0.025>0.0125$ & & \\
\hline
\end{tabular}

All the values are in seconds. Results of the coronary cine-angiogram on the 9 patients are on the right. 
wald and Morrow, 1957; Haber and Leatham, 1965). It cannot be construed to represent decreased myocardial contractility even though pathological studies indicate that most cases of left bundle-branch block are associated with some coronary or myocardial disease (Scott, 1965; Bauer, 1964; Johnson et al., 1951). Haemodynamic studies in intermittent left bundle-branch block have shown that there is a significant fall in left ventricular work as measured by pressure and stroke index only during the period of abnormal conduction (Bourassa et al., 1962).

Group II (patients with infarction) had a significantly shorter isovolumic contraction and longer ventricular ejection than Group $I$, as measured from the apex cardiogram and ventricular pressure pulse.

The relatively normal isovolumic contraction in patients with left bundle-branch block and myocardial infarction suggests that the conduction abnormality in these patients may be more peripherally located, or that compensatory mechanisms in the remaining myocardium may have enhanced the contractility of these areas. The prolonged ejection period would be consistent with dyssynergia in contraction of the ventricle. There is no evidence that the degree of hypertension differed in the two groups. An alternative explanation would be that these patients have a higher left ventricular enddiastolic pressure, but this is not borne out in the patients who were catheterized.

The separation of the two groups suggests that the apex cardiogram may be a simple and practical method of recognizing myocardial infarction in patients with left bundle-branch block.

\section{SUMMARY}

Forty patients, 14 women and 26 men, whose ages ranged from 33 to 88 years, were studied. The history and the vectorcardiogram using the Frank corrected lead system were used to separate the patients into two groups (Neuman et al., 1965; Doucet et al., 1966): Group I patients with uncomplicated left bundle-branch block, and Group II patients with left bundle-branch block complicated with myocardial infarction. The apex cardiogram was recorded according to the method of Benchimol and Dimond (1963). Cardiac catheterization with simultaneous apex cardiogram, phonocardiogram, and electrocardiogram supplemented by coronary cine-angiogram were carried out in 9 patients: 6 in Group II and 3 in Group I.

The isovolumic contraction period was shorter, and the ventricular ejection period was significantly longer in Group II patients compared to Group I, as measured indirectly from the apex cardiogram and directly from the left ventricular pressure pulse. The ventricular systole and isovolumic relaxation period were not significantly different between the two groups.

It is concluded that a short isovolumic contraction and prolonged ejection phase in left bundle-branch block correlated with historical and vectorcardiographic evidence of previous myocardial infarction is a useful sign of myocardial infarction in the presence of this conduction abnormality.

\section{REFERENCES}

Bauer, G. E. (1964). Bundle-branch block: Some usual and some unusual features. Aust. Ann. Med., 13, 62.

Benchimol, A., and Dimond, E. G. (1963). The normal and abnormal apexcardiogram. Its physiologic variation and its relation to intracardiac events. Amer. f. Cardiol., 12, 368.

Bourassa, M. G., Boiteau, G. M., and Allenstein, B. J. (1962). Hemodynamic studies during intermittent left bundlebranch block. Amer. F. Cardiol., 10, 792.

Braunwald, E., and Morrow, A. G. (1957). Sequence of ventricular contraction in human bundle-branch block. Amer. F. Med., 23, 205.

Coblentz, B., Harvey, R. M., Ferrer, M. I., Cournand, A., and Richards, D. W., Jr. (1949). The relationship between electrical and mechanical events in the cardiac cycle of man. Brit. Heart f., 11, 1.

Coulshed, N., and Epstein, E. J. (1963). The apex cardiogram: its normal features explained by those found in heart disease. Brit. Heart F., 25, 697.

Doucet, P., Walsh, T. J., and Massie, E. (1966). A vectorcardiographic and electrocardiographic study of left bundle-branch block with myocardial infarction. Amer. f. Cardiol., 17, 171.

Gray, I. R. (1956). Paradoxical splitting of the second heart sound. Brit. Heart $\mathcal{F}$., 18, 21.

Haber, E., and Leatham, A. (1965). Splitting of heart sounds from ventricular asynchrony in bundle-branch block, ventricular ectopic beats, and artificial pacing. Brit. Heart F., 27, 691.

Johnson, R. P., Messer, A. L., Shreenivas, and White, P. D. (1951). Prognosis in bundle-branch block. II. Factors influencing the survival period in left bundle-branch block. Amer. Heart f., 41, 225.

Keith, N. M., Wagener, H. P., and Barker, N. W. (1939). Some different types of essential hypertension: Their course and prognosis. Amer. F. med. Sci., 197, 332.

Kistin, A. D. (1949). Observations on the anatomy of the atrioventricular bundle (bundle of $\mathrm{His}$ ) and the question of other muscular atrioventricular connections in normal human hearts. Amer. Heart F., 37, 849.

LaDue, J. S., Wróblewski, F., and Karmen, A. (1954). Serum glutamic oxaloacetic transaminase activity in human acute transmural myocardial infarction. Science, $120,497$.

Leatham, A. (1954). Splitting of first and second heart sounds. Lancet, 2, 607.

Lewis, J. K. (1934). Nature and significance of heart sounds and of apex impulses in bundle-branch block. Arch. intern. Med., 53, 741.

Neuman, J., Blackaller, J., Tobin, J. R., Jr., Szanto, P. B., and Gunnar, R. M. (1965). The spatial vectorcardiogram in left bundle-branch block. Amer. F. Cardiol., 16, 352 . 
Reeves, T. J., Hefner, L. L., Jones, W. B., Coghlan, C., Prieto, G., and Carroll, J. (1960). The hemodynamic determinants of the rate of change in pressure in the left ventricle during isometric contraction. Amer. Heart f., 60, 745.

Sambhi, M. P. (1960). The isometric period of contraction as a determinant of cardiac performance and digitalis action. Amer. f. Cardiol., 6, 1042.

Santos, D. E., de la Paz, A. G., Ninos, N. P., Tobin, J. R., Jr., and Gunnar, R. M. (1966). Phentolamine (Regitine) test in cerebrovascular accidents. Arch. intern. Med., 117, 752.

Scott, R. C. (1965). Left bundle-branch block-A clinical assessment. Part I. Amer. Heart f., 70, 535.

Siegel, J. H., and Sonnenblick, E. H. (1963). Isometric time-tension relationships as an index of myocardial contractility. Circulat. Res., 12, 597.

Stewart, T. W., and Warburton, F. G. (1961). Serum lactic dehydrogenase estimations in myocardial infarction. Brit. Heart f., 23, 236.

Tafur, E., Cohen, L. S., and Levine, H. D. (1964). The normal apex cardiogram. Its temporal relationship to electrical, acoustic, and mechanical cardiac events. Circulation, 30, 381.

Tavel, M. E., Campbell, R. W., Feigenbaum, H., and Steinmetz, E. F. (1965). The apex cardiogram and its relationship to haemodynamic events within the left heart. Brit. Heart F., 27, 829.

Wallace, A. G., Mitchell, J. H., Skinner, N. S., and Sarnoff, S. J. (1963). Duration of the phases of left ventricular systole. Circulat. Res., 12, 611.

Wolferth, C. C., and Margolies, A. (1935). Asynchronism in contraction of the ventricles in the so-called common type of bundle-branch block: Its bearing on the determination of the side of the significant lesion and on the mechanism of split first and second heart sounds. Amer. Heart F., 10, 425. 